\author{
(c) (i) (8) \\ JurnalTerapanManajemendan Bisnis is licensed under \\ A Creative Commons Attribution-NonCommercial 4.0 International License.
}

\title{
THE EFFECT OF TRUST DIMENSION TO E-COMMERCE COSTUMERS PARTICIPATION (CASE STUDY TO E-COMMERCE COSTUMERS IN BIMA CITY)
}

\author{
Ismunandar ${ }^{1)}$, Mulyadin'2) \\ 1) Sekolah Tinggi Ilmu Ekonomi (STIE) Bima, Bima, Indonesia \\ E-mail: andar.stiebima@gmail.com \\ 2) Sekolah Tinggi Ilmu Ekonomi (STIE) Bima, Bima, Indonesia \\ E-mail: andar.stiebima@gmail.com
}

\begin{abstract}
Transactions through e-commerce have a high potential risk. Therefore, the trust factor of customers towards the vendor becomes a key factor in e-commerce. Indonesia as a developing country and about the last five years adopted e-commerce, absolutely, has some differences with developed countries that have been long practicing it. These differences are at least related to regulatory issues, legal device, and consumer behavior. In relation to the ecommerce practice in Bima city that is still relatively new, the interesting phenomenon to be studied is the extent to which customers trust and how it affects the level of customer participation in e-commerce. The aims of this research are (1) to analyze the effect of the trust dimension variable which includes ability, virtue, and integrity to Indonesian costumers participation; (2) As information about the trust dimension of costumers e-commerce in Bima city, so the company can choose the right strategy to improve trust and people participation in using e-commerce as a future business transaction system. The study has been conducting in Bima city for 1 year from December 2017 to December 2018. This research is divided into several steps, namely 1) Preparation (2) Implementation, (3) Reporting, (4) Monitoring, evaluation, and dissemination. The technique of data collection used in this study that is (1) Questionnaire, (2) Observation, (3) Study book. Technique of Data Collection used is multiple regression analysis using equation, that is: $\mathrm{Y}=\mathrm{a}+\mathrm{b} 1 \mathrm{x} 1+$ $b 2 \times 2+b 3 \times 3$. The results of the study concluded that the dimensions of trust, ability, and benevolence have a positive and significant effect on the participation of e-commerce customers in Bima City. While variable integrity does not have a positive and significant effect. Meanwhile, testing these three variables together has a positive and significant influence.
\end{abstract}

Keywords: e-commerce; participation; ability; benevolence; Integrity

\section{Introduction}

Online developments are now increasingly varied, one of which is the use of the internet for buying and selling transactions. Indonesia as one of the developing countries in the world has some significant differences in practicing e-Commerce when compared to other modern countries in terms of the regulation, law and customers' attitude (Rofiq, 2015). The 
number of online buying and selling transactions that continue to increase dramatically from year to year shows that online business will grow further, and it is estimated that this positive trend will continue for the next five years (Septania, 2018). Data and facts about the increasing number of online transactions have made many business people who have begun to switch to the online business world.

E-commerce is a new breakthrough in the world of information, because it can provide information in a more attractive, fun and online form at any time without time limits, provided that all technological devices meet. In this regard, established companies make objects in the application of marketing through e-Commerce (Maulina, 2004). In terms of marketing, trust is something that is absolutely there because trust is the foundation of marketing. Relationship in marketing requires trust. That is, without trust means it won't a relationship occurs (Utami, 2010).

Bima City is one of the cities that is quite advanced in terms of communication and information, this is evident from the last decade the city of Bima has experienced rapid development and is not inferior to other major cities in West Nusa Tenggara such as the City of Mataram. Almost every village there are internet cafes, not to mention the increasingly dynamic lifestyle so that in every corner of the cafe and places to gather and in the middle of the field even though there is also an internet network in the form of wi-fi to every home and boarding house there is also a subscription internet network. Indirectly lead to a consumptive lifestyle towards an item. This encourages someone to try to do transactions via the internet (e-commerce). In addition, e-commerce actors who sell their own products must ensure that all the basic materials needed to design their products must remain (Potitwika, 2017).

The main key to the company's success in the internet era is determined by its ability to meet the needs and desires of its consumers. This can be done if Marketers understand the behavior of consumers. Unfortunately to understand this is not an easy thing because consumer behavior is quite complex and multidimensional (Suryani, 2008).

Bima city as a developing city, and only in the last few years has adopted ecommerce, certainly has some differences with other cities that have long practiced ecommerce. These differences are at least related to the problem of technological development in a region and consumer behavior. In connection with e-commerce practices in the relatively new city of Bima, an interesting phenomenon to study is the extent to which e-commerce customers trust in conducting online transactions and how they relate to the level of ecommerce customer participation.

The implications of this study relevant to the online business sector to pay attention to the forming dimensions trust in influencing individual participation of e-commerce users (Rasoki, 2015). This study aims to (1) find out and analyze the positive and significant influence of the Trust (Trust) dimension which consists of ability, benevolence and Integrity on the participation of E-Commerce customers in Bima City (2) the extent to which the Bima City community knows E-Commerce (3) Introducing the right marketing statistics in doing business online and paying attention to things that can affect the public interest to be involved in the online business world, one of which is trust.

\section{Research Methods}

The type of research used in this study is using associative or causal research. The population in this study were all internet users in the city of Bima who had done e-commerce transactions, the samples in this study were 65 people. The variables in this study are the Trust dimension, namely Ability (ability) (X1), benevolence (X2) and integrity (integrity) (X3) and participation as the dependent variable $(\mathrm{Y})$ with several indicators as a benchmark for 
seeing the effect between variables $\mathrm{X}$ and variable $\mathrm{Y}$. Measurement of variables using Likert's scale. Data collection techniques used in this study are (1) Questionnaire, (2) Observation, (3) Literature study. Testing the data using validity test by stating that if the validity of each statement is greater than 0.30 or $>0.30$ then the question item is considered valid and reliability testing is determined by the Cronbach's Alpha coefficient by requiring a reliable instrument if it has a Cronbach's Alpha coefficient above 0.60 or $>0.60$ (Sugiyono, 2011). The data analysis technique used is multiple linear regression analysis using the equation, $\mathrm{Y}=\mathrm{a}+$ $b_{1} x_{1}+b_{2} x_{2}+b_{3} x_{3}$.

To see whether the independent variables (ability, goodness, and integrity) together influence the dependent variable (the participation of e-commerce customers in Bima City) then the $\mathrm{F}$ test is performed, the determination of significance is done by comparing $\mathrm{F}$ count with $\mathrm{F}$ table, if the value is identified as $\mathrm{F}$ count $>\mathrm{F}$ table, then Zero Hypothesis is rejected, on the contrary if $\mathrm{F}$ count $<\mathrm{F}$ table, then Zero/Ho Hypothesis is accepted. To test the significance of the effect of the independent variable on the dependent variable, a partial t-test is performed on the regression coefficient. The hypothesis in t-test is Ho, meaning that there is no significant effect on $\mathrm{Y}$, while $\mathrm{H} 1$ means that variable $\mathrm{X}$ has a significant effect on $\mathrm{Y}$. Ho is rejected and $\mathrm{Ha}$ is accepted if the value of $\mathrm{t}$-counts more than $\mathrm{t}$-table ( $\mathrm{t}$-hit $>\mathrm{t}$-tab) in regression analysis and test. This is done using SPSS 16 for windows. Against the variables, correlation analysis is performed to determine the shape and strength of the relationship of the independent variables to the dependent variable.

\section{Results and Discussion \\ Validity Test}

Table 1 Validity Test Results

\begin{tabular}{ccc}
\hline r Count Variable & r Table & Information \\
\hline (X1.1) 0,627 & 0,300 & Valid \\
(X1.2) 0,715 & 0,300 & Valid \\
(X1.3) 0,642 & 0,300 & Valid \\
(X1.4) 0,750 & 0,300 & Valid \\
(X2.1) 0,699 & 0,300 & Valid \\
(X2.2) 0,795 & 0,300 & Valid \\
(X2.3) 0,755 & 0,300 & Valid \\
(X3.1) 0,610 & 0,300 & Valid \\
(X3.2) 0,706 & 0,300 & Valid \\
(X3.3) 0,619 & 0,300 & Valid \\
(Y.1) 0,594 & 0,300 & Valid \\
(Y.2) 0,775 & 0,300 & Valid \\
(Y.3) 0,712 & 0,300 & Valid \\
\hline
\end{tabular}

Source: Data processed in 2018

Based on Table 1, the results of testing the validity of the Trust (Ability, Benevolence, and Integrity) dimension variables on E-Commerce Customer' Participation can be said to be valid in corrected item-total correlation $>0.300$. The results of this validity test indicate that the questionnaire statement in this study is valid. 
Table 2 Reliability Test Results

\begin{tabular}{ccc}
\hline Variable & Cronbach Alpha & Information \\
\hline Ability $(\mathrm{X} 1)$ & .621 & Reliable \\
Benevolence $(\mathrm{X} 2)$ & .617 & Reliable \\
Integrity $(\mathrm{X} 3)$ & .661 & Reliable \\
Participation $(\mathrm{Y})$ & .620 & Reliable \\
\hline
\end{tabular}

Source: Data processed in 2018

Based on Table 2, the results of testing the study using this measurement can be said to be reliable in Cronbach alpha $>0.600$. The reliability testing results show that the questionnaire statement in this study is reliable.

Classic Assumption Test

For the multi-collinearity test, it was found that there are no variables that have a VIF value greater than 10 and a tolerance value smaller than $10 \%$.

Table 3 Reliability Test Results

\begin{tabular}{cccc}
\hline \multirow{2}{*}{ Model } & \multicolumn{2}{c}{ Collinearity Statistics } & \multirow{2}{*}{ Information } \\
\cline { 2 - 3 } & Tolerance & VIF & \\
\hline Ability & .829 & 1.207 & Free of Multi-collinearity \\
Benevolence & .642 & 1.557 & Free of Multi-collinearity \\
Integrity & .553 & 1.808 & Free of Multi-collinearity \\
\hline
\end{tabular}

Source: Data processed in 2018

For testing heteroscedasticity, it can be seen at the table below that the points that spread randomly, do not form a certain clear pattern and spread both above and below the 0 (zero) on the Y-axis, so there is no heteroscedasticity. To test the normality of the data, the histogram graph and the normal probability plot show that the data is scattered around the diagonal line, then the regression model meets the assumption of normality.

\section{Multiple Linear Regression}

Multiple regression analysis was chosen to analyze the submission of hypotheses in this study. Testing is done using the SPSS 16.00 program for Windows.

Table 4 Coefficients ${ }^{\mathrm{a}}$

\begin{tabular}{|c|c|c|c|c|c|c|c|}
\hline \multirow{2}{*}{ Model } & \multicolumn{2}{|c|}{$\begin{array}{c}\text { Unstandardized } \\
\text { Coefficients }\end{array}$} & \multirow{2}{*}{$\begin{array}{c}\begin{array}{c}\text { Standardized } \\
\text { Coefficients }\end{array} \\
\text { Beta }\end{array}$} & \multirow{2}{*}{$\mathbf{t}$} & \multirow{2}{*}{ Sig. } & \multicolumn{2}{|c|}{ Collinearity Statistics } \\
\hline & B & $\begin{array}{l}\text { Std. } \\
\text { Error }\end{array}$ & & & & Tolerance & VIF \\
\hline (Constant) & 1.795 & 1.425 & & 1.259 & .213 & & \\
\hline Ability & .245 & .092 & .278 & 2.664 & .010 & .829 & 1.207 \\
\hline Benevolence & .334 & .102 & .389 & 3.277 & .002 & .642 & 1.557 \\
\hline Integrity & .172 & .108 & .204 & 1.595 & .116 & .553 & 1.808 \\
\hline
\end{tabular}

a. Dependent Variable: Participation

Source: Data processed in 2018 
From the results of regression analysis can be known multiple linear regression equation as follows:

$$
\mathrm{Y}=1.795+0.245 \mathrm{X}_{1}+0.334 \mathrm{X}_{2}+0.172 \mathrm{X}_{3}
$$

Based on these equations, it can be explained as follows:

a. A constant value of 1,795 can be interpreted if the variables Ability, Benevolence and Integrity are considered zero, then Participation will be 1,795.

b. The beta coefficient value on the Ability variable is 0.245 , meaning that each change in Ability variable $(\mathrm{X} 1)$ is one unit, it will lead to Participation $(\mathrm{Y})$ changes of 0.245 units, with other assumptions being fixed.

c. The Beta coefficient value on benevolence variable is 0.334 meaning that every change in benevolence $(\mathrm{X} 2)$ variable of one unit will result in changes in Participation $(\mathrm{Y})$ of 0.334 units, with other assumptions being fixed.

$\mathrm{d}$. The Beta coefficient value on the Integrity variable is 0.172 , meaning that every change in Integrity (X3) variable of one unit will result in Participation (Y) changes of 0.172 units, with other assumptions being fixed.

\section{Multiple Correlation Test and Determination Test}

Multiple correlation analysis to determine the degree or strength of the relationship between two variables, Multiple correlation tests can be done using SPSS 16.0 For Windows data processing application program.

Table 5 Summary model

\begin{tabular}{ccccc}
\hline Model & R & R Square & $\begin{array}{c}\text { Adjusted R } \\
\text { Square }\end{array}$ & $\begin{array}{c}\text { Std. Error of } \\
\text { the Estimate }\end{array}$ \\
\hline 1 & $.669^{\mathrm{a}}$ & .448 & .421 & .965 \\
\hline
\end{tabular}

a. Predictors: (Constant), Integrity, Ability, Benevolence

b. Dependent Variable: Participation

Source: Data processed in 2018

Based on the table of multiple correlation test results, it can be explained that the correlation between Ability (X1), Benevolence (X2) and Integrity (X3) variables on ECommerce Customer Participation $(\mathrm{Y})$ is 0.669 (Strong relationship level. Based on the table, the coefficient of determination ( $\mathrm{R} 2$ ) is 0.448 , which means that the contribution of Ability $(\mathrm{X} 1)$, Benevolence $(\mathrm{X} 2)$ and Integrity (X3) affects the E-Commerce Customer Participation (Y) by $44.8 \%$. The participation of E-Commerce Customers is determined Ability (X1), Benevolence (X2) and Integrity (X3) of $44.8 \%$ and the remaining $55.2 \%$ are influenced by other variables.

\section{Hypothesis Test Results}

T-Test (Partial)

Furthermore, to find out whether the hypothesis proposed in this study is accepted or rejected, hypothesis testing will be conducted using the t-test. The results of testing the hypothesis are explained as follows:

a. The $t$ count value on the Ability variable (X1) is 2.664 with a significance level of 0.010 . Because $2.664>1.999$ and $0.010<0.05$, Ho is rejected and Ha is accepted.

Conclusion: ability variable has a positive and significant effect on the participation of ecommerce customers in the city of Bima.

b. The $t$ count value in the Benevolence $(\mathrm{X} 2)$ variable is 3.277 with a significance level of 0.002. Because $3.277>1.998$ and $0.002<0.05$, Ho is rejected and Ha is accepted. 
Conclusion: Benevolence variable has a positive and significant effect on the participation of e-commerce customers in the city of Bima.

c. The t count value on the Integrity (X3) variable is 1.595 with a significance level of 0.116 . Because $1.595<1.998$ and $0.116<0.05$, Ha is rejected and Ho is accepted.

Conclusion: variable integrity does not have a positive and significant effect on the participation of e-commerce customers in the city of Bima.

F Test (Simultaneous)

Tabel 6 Anova $^{a}$

\begin{tabular}{lrcccc}
\hline Model & Sum of Squares & df & Mean Square & F & Sig. \\
\hline 1 Regression & 46.158 & 3 & 15.386 & $.000^{\mathrm{b}}$ & \\
Residual & 56.827 & 61 & .932 & & \\
Total & 102.985 & 64 & & & \\
\hline
\end{tabular}

a. Dependent Variable: Participation

b. Predictors: (Constant), Integrity, Ability, Benevolence

Source: Data processed in 2018

The influence of independent variables testing simultaneously on the dependent variable is done by using the $\mathrm{F}$ test. The results of statistical calculations show the $\mathrm{F}$ value calculated $=16.516$, with a significance of $0.000<0.05$. This means that simultaneously Ability $(\mathrm{X} 1)$, Benevolence $(\mathrm{X} 2)$ and Integrity (X3) education has an effect on E-Commerce (Y) Customer Participation in Bima City.

\section{Conclusion}

The people of Bima City have begun to recognize and use online buying and selling transactions. This can be evidenced by research conducted by researchers, where the dimensions of trust (ability) and benevolence have a positive and significant effect on the participation of e-commerce customers in Bima City. While variable integrity does not have a positive and significant effect. Meanwhile, testing these three variables together has a positive and significant influence. The existence of an online buying and selling application has made the city of Bima more intensive in conducting e-commerce activities that have an impact on the growth of businesses that sell online.

\section{Reference}

Maulina, D. (2004). E-Commerce Sebagai Pendukung Pemasaran Perusahaan. https://wahyusuryandari.wordpress.com/2009/05/27/lima-jurnal-tentang-ecommerce/. (Accessed July 24, 2018).

Potitwika. (2017). 99 Langkah Sukses Berbisnis E-Commerce. Jakarta: Gramedia Widiasarana Indonesia.

Rasoki, I. (2015). Analisis Dimensi Kepercayaan Terhadap Partisipasi Individu Pengguna ECommerce (Studi pada individu pengguna internet pada forum oline Kaskus). Jurnal Ilmiah Mahasiswa FEB 1(1).

Rofiq, A. (2007). Pengaruh Dimensi Kepercayaan (Trust) Terhadap Partisipasi Pelanggan ECommerce (Studi Pada Pelanggan E-Commerce di Indonesia). (Accessed February 18, 2017).

Septania, R. C. (2108). Pengguna Internet Indonesia Nomor Enam Dunia. http://tekno.kompas.com/read/2014/11/24/07430087/Pengguna.Internet.Indonesia.No. or.Enam.Dunia. (Accessed February 22, 2018).

Sugiyono. (2011). Metode Penelitian Kualitatif, Kuantitatif, dan RED. Bandung: Alfabeta. 
Jurnal Terapan Manajemen dan Bisnis

Volume 4 Number 2 September 2018. Page 138-144

e-ISSN: 2477-5282 p-ISSN: 2599-3127

Suryani, T. (2008). Perilaku Konsumen: Implementasi pada strategi Pemasaran. Edisi pertama Cetak pertama. Jakarta: Graha Ilmu.

Utami, N. (2010). Pengaruh Dimensi Kepercayaan (Trust) terhadap Perilaku Konsumen dalam Membeli Barang Secara Online (Studi Kasus Toko Online Milchop Butik). Jurnal UIN Syarif Hidayatullah Jakarta. 